\title{
Aripiprazole use in Children and Adolescents: A Public Hospital Child Psychiatry Outpatient Department's Experience
}

\author{
Saziye Senem Basgul ${ }^{1}$
}

ÖZET:

Çocuklarda ve gençlerde aripiprazol kullanımı: Bir devlet hastanesi çocuk psikiyatrisi polikliniği deneyimi

Dopamin-serotonin sistem dengeleyicisi olarak adlandırılan aripiprazol, farklı reseptör etkinliği nedeniyle şizofreni, bipolar bozukluk ve yaygın gelişimsel bozukluğu olan çocuk ve gençlerde giderek artan oranda kullanıımaya başlanmıştır. Çalışmamızda şizofreni, bipolar bozukluk, yaygın gelişimsel bozukluk, depresyon, dikkat eksikliği hiperaktivite bozukluğu, tik bozukluğu, obsesif kompulsif bozukluk, mental reterdasyon ve sınır kişilik bozukluğu tanılarından bir veya birkaçını alan 41 olguda aripiprazol kullanılmıştır. Aripiprazol $4 \mathrm{mg} \pm 1,5 \mathrm{mg} /$ gün başlanmış, $18,5 \pm 1,5 \mathrm{mg} /$ gün doza çıkılmış, ortalama doz $10 \mathrm{mg} /$ gün olarak kullanılmıştır. Klinik Global İzlenim Ölçeği puan ortalamaları başlangıçta $4,7 \pm 0,85$ puan iken, bir aylık tedavi takibinde $2,3 \pm 0,97$ puana düşmüştür. Aripiprazol kullanımına bağlı 9 olguda yan etki görülmüştür $(\% 21,9)$. Bu yan etkiler akatizi, sinirlilik, uykusuzluk, uyuşukluk ve uyuklama, mevcut takıntılarda artma, iştah ve kilo artışı olarak belirlenmiştir. Olguların 36'sı $(\% 87,8)$ tedaviyi devam ettirirken, $5^{\prime} i(\% 12,2)$ yan etki nedeniyle ilaç tedavisini bırakmıştır. Tedaviye yanıtsızlık nedeniyle ilaç kesilen hiçbir olgu olmamıştır. Aripiprazol çocuk ve gençlerde güvenilir ve etkin bir seçenek gibi görünmektedir

Anahtar sözcükler: aripiprazol, psikiyatrik hastalıklar, çocuk ve genç

Klinik Psikofarmakoloji Bulteni 2014;24(1):31-8

\section{ABSTRACT:}

Aripiprazole use in children and adolescents: a public hospital child psychiatry outpatient department's experience

Aripiprazole is a dopamine-serotonin system stabilizer and increasingly, its use is more common in children and adolescents with schizophrenia, bipolar disorder and pervasive developmental disorder due to its effectiveness on different types of receptors We used aripiprazole in 41 patients with one or more of the following diagnoses in this study: schizophrenia, bipolar disorder, pervasive developmental disorder, depression, attention deficit hyperactivity disorder, tic disorder, obsessive compulsive disorder, borderline personality disorder, mental retardation. Aripiprazole 4 $\mathrm{mg} \pm 1.5 \mathrm{mg} /$ day was started and titrated up to $18.5 \pm 1.5$ $\mathrm{mg} /$ day with a mean dose of $10 \mathrm{mg} / \mathrm{day}$. The mean Clinical Global Impression Scale score was $4.7 \pm 0.85$ initially and decreased to $2.3 \pm 0.97$ points at one-month follow-up. Side effects related to aripiprazole use were seen in 9 cases (21.9\%). These side effects were akathisia, irritability, insomnia, lethargy and sleepiness, increase in current obsessions, increased appetite and weight gain. While $36(87.8 \%)$ cases continued the treatment, 5 (12.2\%) patients discontinued the drug treatment due to the side effects. There was no case where the drug was discontinued due to lack of response to treatment. Aripiprazole may be a reliable and efficacious choice in children and adolescents.

Keywords: aripiprazole, psychiatric disorders, children and adolescents

Bulletin of Clinical Psychopharmacology 2014;24(1):31-8
'M.D., Istanbul Medeniyet University Goztepe Training and Research Hospital, Istanbul - Turkey

Address reprint requests to: Spec. Dr. Şaziye Senem Başgül, Istanbul Medeniyet University, Goztepe Research and Training Hospital, Department of Child Psychiatry, Göztepe, Istanbul - Turkey

Phone: +90-532-474-6004

E-mail address: senembasgul@gmail.com

Date of submission: June 19, 2012

Date of acceptance: December 03, 2012

Declaration of interest:

S.S.B.: The author reported no conflict of interest related to this article.

\section{INTRODUCTION}

Aripiprazole, an atypical antipsychotic, is a partial agonist of pre- and post-synaptic dopamine D2 receptors and a strong agonist of the D3 receptor. It avoids extrapyramidal symptoms by decreasing dopaminergic activity in the nigrostriatal system and balances dopaminergic neurons ${ }^{1}$. Aripiprazole is also a partial agonist of serotonin 5-HT1A and 5-HT2C receptors and an antagonist of the 5-HT2A receptor ${ }^{2}$. Its weak effect on histamine $\mathrm{H} 1$ 
receptors and $\alpha 1$-adrenergic receptors and lack of effect on muscarinic receptors are important in terms of fewer side effects. Aripiprazole is converted to the active metabolite dehydroaripiprazole by cytochrome P4503A4 and 2D6 in the liver. Dehydro-aripiprazole binds to the D2 receptor and has activity similar to the parent compound. The elimination half-life is 75 to 94 hours ${ }^{3}$.

The most common side effects observed with the use of atypical antipsychotics in children and adolescents are weight gain, lethargy, hyperglycemia, diabetes, hyperlipidemia, QT interval prolongation, and increased salivation ${ }^{4,5}$. Antipsychotics can also have side effects such as gynecomastia, galactorrhea, delayed puberty or amenorrhea due to hyperprolactinemia, and decreased bone mineral density ${ }^{6,7}$. A lower rate of adverse effects or side effects has been reported in studies conducted in adults where aripiprazole, a second-generation antipsychotic, was compared with other typical and atypical antipsychotics. Minimal weight gain and no change in the QT interval and prolactin level were reported. Akathisia was the most frequently reported symptom in these studies ${ }^{8,9}$. Aripiprazole is reported to have a lower incidence of side effects due to its receptor binding characteristics and it may be a safe option in child and adolescent psychiatry ${ }^{10,11}$.

Aripiprazole is reported to be effective in child and adolescent patients with schizophrenia, bipolar disorder (BPD), attention deficit hyperactivity disorder (ADHD), pervasive developmental disorder (PDD), tic disorder (TD) and obsessive-compulsive disorder (OCD) ${ }^{10,12-22}$. Findling et al. reported from their multi-center, randomized, double-blind, placebo-controlled study that $10-30 \mathrm{mg} /$ day of aripiprazole was safer and more effective than placebo in the acute treatment of schizophrenia in adolescents aged 13 to $17^{12}$. Aripiprazole treatment started at $5-15 \mathrm{mg} /$ day and continued with a maintenance dose of $5-20 \mathrm{mg} /$ day was used in the treatment of bipolar disorder in children and adolescents in a study on the use of aripiprazole in bipolar disorder in childhood in 24 cases with ages ranging from 5 to $17^{13}$. A double-blind, randomized, placebocontrolled, follow-up study concluded that aripiprazole was effective and reliable in children with BPD aged 4 to 9 years ${ }^{14}$. A study evaluating side effects reported that aripiprazole was well tolerated and the most common side effects were nausea, insomnia, vomiting, and agitation in 41 BPD patients aged 4 to 17 years, who had previously been treated with other antipsychotics without satisfactory results and had then been started aripiprazole ${ }^{15}$. Aripiprazole was reported to be effective for irritability and other destructive behavior in a double-blind, randomized, placebocontrolled study, where 218 patients with autism between the ages of 6-17 were included ${ }^{16}$. Aripiprazole was observed to be effective on aggression, anger outbursts and self-harming behavior in 28 children with a mean age of $14.41 \pm 2.5$ years followed up in the Göztepe Training and Research Hospital of which 13 had PDD and 15 had mental retardation. Aripiprazole was started at $2.5 \mathrm{mg}$ in these children and titrated up to a dose of 5-15 mg in day ${ }^{17}$. A number of other case series have reported aripiprazole to be effective in the treatment of $\mathrm{TD}^{18-19}$. Aripiprazole was found to be effective with the main side effects of vomiting and drowsiness in the study of Findling et al., who investigated the effectiveness of aripiprazole in disruptive behavior disorders in children and adolescents ${ }^{20}$. It has also been reported to be effective for resistant OCD symptoms ${ }^{21}$. It is thought that aripiprazole might also be useful in the treatment of other psychiatric disorders that affect cognitive functions such as ADHD, due to its unique receptor-binding profile $^{22}$. An average of $8.55 \mathrm{mg} /$ day $(\mathrm{SD}=1.73$ ) aripiprazole was found to control the ADHD and BD symptoms in 20 children with behavioral disorder (BD) in a study conducted in Turkey ${ }^{23}$. The effectiveness of aripiprazole on seven cases with the diagnosis of BPD, early-onset schizophrenia, mental retardation, major depressive disorder and OCD was evaluated in case series reported by Bildik et al. As a result of this study, aripiprazole was recommended as an 
effective and safe option in the treatment of manic and psychotic symptoms, aggression, ADHD symptoms and OCD symptoms in children and adolescents ${ }^{24}$.

Aripiprazole obtained the approval of the Ministry of Health for the treatment of autism associated with irritability in patients aged 6 to 17 years and childhood schizophrenia in children and adolescents aged 13 to 17 years in our country. FDA approval is in place for the treatment of bipolar disorder manic attacks in children aged 10 to 17 years in addition to these indications from countries other than the U.S.A. ${ }^{10}$.

We aimed to evaluate the indication, efficacy and side effects of aripiprazole in a group of children, who presented to the pediatric outpatient department and for whom aripiprazole was preferred in this study. We share our experience with the use of this increasingly popular drug in the field of child and adolescent psychiatry on 41 patients.

\section{METHOD}

This study is a retrospective study. We included 41 patients, who presented to the psychiatry department of a public hospital in Istanbul and were put on aripiprazole. Cases that were followedup at the outpatient clinic with different diagnoses and had been started aripiprazole within the last month were selected by chart review. This study was continued between March 2011 and December 2011. The diagnoses of the patients that agreed to participate in the study were reevaluated by the investigator, a child psychiatry specialist, with a psychiatric clinical interview based on DSM-IV criteria. The aim of the study was explained to the families of the patients and their consent was obtained.

The Clinical Global Monitoring Scale (CGM-S) and a socio-demographic information and follow up form prepared by a child psychiatrist for this study were used to gather data. The CGM-S was administered before the treatment and during the outpatient follow-up 1 month after aripiprazole treatment was started.
Clinical Interview: A clinical interview according to DSM-IV diagnostic criteria was used for the diagnosis and differential diagnosis of the 41 children (and their families), who were followed up by a child psychiatrist at the outpatient department and for whom aripiprazole was preferred for the treatment. Axis 1 and Axis 2 diagnoses were evaluated ${ }^{25}$. The efficacy and side effects of the drug were evaluated during the interview performed with the child and the family at the end of the first month of the aripiprazole treatment. Patients were then followed as outpatients. Side effects were determined by asking whether the most commonly reported side effects associated with the use of aripiprazole such as extrapyramidal system findings, headache, insomnia, nausea, vomiting, trouble sleeping, constipation, and weight change or other side effects were present.

Clinical Global Monitoring Scale (CGM-S): The CGM-S is a scale that evaluates the general improvement in severity or symptoms of any disease. The clinician who uses the scale evaluates the degree of severity or improvement of the disease with a Likert-type scale between 1 and 7 (1 - normal, not ill, 2 - borderline ill, 3 - mildly ill, 4 moderately ill, 5 - markedly ill, 6 - severely ill, 7 extremely ill) based on knowledge and experience related to the disease in question ${ }^{26}$. The CGM-S was administered to the patients before the treatment and again at the end of the first month of treatment.

Socio-demographic information and follow up form: This form was prepared by the child psychiatrist. Information about the ages of the children, diagnoses, the age of diagnosis, initial aripiprazole dose and dose increases, and side effects were queried and noted on the form.

\section{Statistics}

The statistical data were evaluated with SPSS 10.0 for Windows and descriptive statistics were used. 


\section{RESULTS}

Of the 41 cases included in the study, 29 (70.7\%) were male and 12 (29.3\%) female. The cases were between the ages of 8 and 20 years. The mean age was 14.9- \pm 2.6 .

The clinical interviews led to a diagnosis of MR in 19 (46.4\%), autism in 13 (31.7\%), DB in 9 (21.9\%) with BP, OCD in 9 (21.9\%), ADHD in 8 (19.5\%), BPD in $6(14.9 \%)$, depression in $4(9.8 \%)$, TD in $1(2.4 \%)$ and borderline personality disorder in $1(2.4 \%)$ according to the DSM-IV diagnostic criteria. The distribution of the diagnoses is presented in Table 1. There were cases with more than one diagnosis (Table 3). According to the DSM-IV diagnostic classification, MR and NW were coded in axis 2 and the others were coded in axis 1 .

Aripiprazole was started at $4 \pm 1.5 \mathrm{mg} /$ day and titrated up to a dose of $18 \pm 1.5 \mathrm{mg} /$ day. The mean dose was $10 \mathrm{mg} /$ day. Nine cases with OCD had been started on treatment with serotonin reuptake inhibitors (SSRI) previously and this treatment was continued in 5 cases. Of the 8 patients with ADHD, 5 were treated with methylphenidate and 2 with atomoxetine. SSRIs had been started previously in all 4 cases diagnosed with depression and 2 continued to use a SSRI.

Aripiprazole was the first antipsychotic used in 12 cases $(29.3 \%)$. There was a history of the use of antipsychotics with 1 different active substance in 19 cases (46.3\%), 2 different active agents in 7 cases (17.1\%), 3 different active agents in 1 case $(2.4 \%)$ and 4 different active agents in 2 cases $(4.9 \%)$ before the use of aripiprazole. At least 1 antipsychotic started before the aripiprazole treatment was continued with aripiprazole in 10 patients $(24.4 \%)$. Other antipsychotics that had previously been started were risperidone, quetiapine, olanzapine and haloperidol. No changes were made in the drugs that had been used by the patients before aripiprazole was started.

\section{Table 1: Diagnoses of the cases}

\begin{tabular}{lcc} 
DIAGNOSES & Number of cases ( $\mathbf{n})$ & \% \\
\hline Mental Retardation & 19 & 46.4 \\
Autism & 13 & 31.7 \\
Behavioral Disorder & 9 & 21.9 \\
Obsessive Compulsive Disorder & 9 & 21.9 \\
Attention Deficit Hyperactivity Disorder & 8 & 19.5 \\
Bipolar Disorder & 6 & 14.9 \\
Depression & 4 & 9.8 \\
Tic Disorder & 1 & 2.4 \\
Borderline Personality Disorder & 1 & 2.4 \\
\hline
\end{tabular}

Note: Some cases had more than one diagnosis.

Table 2: Distribution of the cases with multiple diagnoses

\begin{tabular}{|c|c|c|c|c|c|c|c|c|c|c|}
\hline DIAGNOSIS & MR (n) & Autism (n) & $B D(n)$ & OCD (n) & ADHD (n) & BPD (n) & MDD (n) & TD (n) & BPD (n) & Total (n) \\
\hline$M R(n)$ & 9 & 4 & 2 & 1 & 0 & 2 & 0 & 1 & 0 & 19 \\
\hline Autism (n) & 4 & 9 & 0 & 0 & 0 & 0 & 0 & 0 & 0 & 13 \\
\hline $\mathrm{BD}(\mathrm{n})$ & 2 & 0 & 2 & 0 & 5 & 0 & 0 & 0 & 0 & 9 \\
\hline $\mathrm{OCD}(\mathrm{n})$ & 1 & 0 & 0 & 6 & 1 & 0 & 0 & 0 & 1 & 9 \\
\hline $\operatorname{ADHD}(n)$ & 0 & 0 & 5 & 1 & 2 & 0 & 0 & 0 & 0 & 8 \\
\hline $\mathrm{BPD}(\mathrm{n})$ & 2 & 0 & 0 & 0 & 0 & 4 & 0 & 0 & 0 & 6 \\
\hline $\operatorname{MDD}(n)$ & 0 & 0 & 0 & 0 & 0 & 0 & 2 & 0 & 0 & 2 \\
\hline $\mathrm{TD}(\mathrm{n})$ & 1 & 0 & 0 & 0 & 0 & 0 & 0 & 0 & 0 & 1 \\
\hline $\mathrm{BPD}(\mathrm{n})$ & 0 & 0 & 0 & 1 & 0 & 0 & 0 & 0 & 0 & 1 \\
\hline Total (n) & 19 & 13 & 9 & 9 & 8 & 6 & 2 & 1 & 1 & 70 \\
\hline
\end{tabular}

MR: mental retardation, BD: behavioral disorder, OCD: obsessive compulsive disorder, ADHD: attention deficit hyperactivity disorder, BPD: bipolar disorder, 
There were no side effects due to the use of aripiprazole in $32(78.1 \%)$ cases. Of the $9(21.9 \%)$ cases that reported side effects, 2 cases had akathisia, 2 irritability, 1 insomnia, 1 drowsiness and sleepiness, 1 an increase in current obsessions and 2 an increase in appetite and weight. One of the cases that had weight gain also described constipation. The first antipsychotic used was aripiprazole in one of the cases that developed akathisia. The other case had a previous history of risperidone and quetiapine use. The use of these active substances had been terminated due to weight gain and partial response. Both patients who gained weight had a previous history of risperidone and quetiapine use. Both cases terminated the drugs due to weight increase and partial response. One of the cases that reported nervousness had a previous history of risperidone and haloperidol use and had discontinued these substances due to unresponsiveness. The other had used risperidone, quetiapine, olanzapine and haloperidol before the use of aripiprazole. Their treatment was discontinued due to side effects of weight gain and nervousness. The case that developed insomnia had previously used risperidone and discontinued treatment because of weight gain. The case whose current obsession increased had previously used risperidone but discontinued it due to unresponsiveness. The case that described sleepiness and drowsiness had used aripiprazole as the first antipsychotic (Table 3).

Of the cases who started aripiprazole, 36

Table 3: Previous antipsychotic use and reason for discontinuation in cases that developed side effects after aripiprazole use

\begin{tabular}{|c|c|c|c|}
\hline Cases that developed side effects ( $21.9 \%)$ & n (\%) & AP previously used & $\begin{array}{l}\text { Reason for discontinuing the } \\
\text { previous AP }\end{array}$ \\
\hline Akathisia & $2(4.9)$ & $\begin{array}{c}\text { none } \\
\text { risperidone, quetiapine }\end{array}$ & partial response \\
\hline Nervousness & $2(4.9)$ & $\begin{array}{l}\text { risperidone, haloperidol } \\
\text { risperidone, quetiapine, } \\
\text { olanzapine, haloperidol }\end{array}$ & $\begin{array}{c}\text { no response } \\
\text { weight gain, no response, } \\
\text { nervousness }\end{array}$ \\
\hline Weight gain & $2(4.9)$ & $\begin{array}{l}\text { risperidone, quetiapine } \\
\text { risperidone, quetiapine }\end{array}$ & $\begin{array}{l}\text { weight gain, partial response } \\
\text { weight gain, partial response }\end{array}$ \\
\hline Insomnia & $1(2.4)$ & risperidone & weight gain, no response \\
\hline Drowsiness and lethargy & $1(2.4)$ & none & \\
\hline Increase in obsessions & $1(2.4)$ & risperidone & no response \\
\hline
\end{tabular}

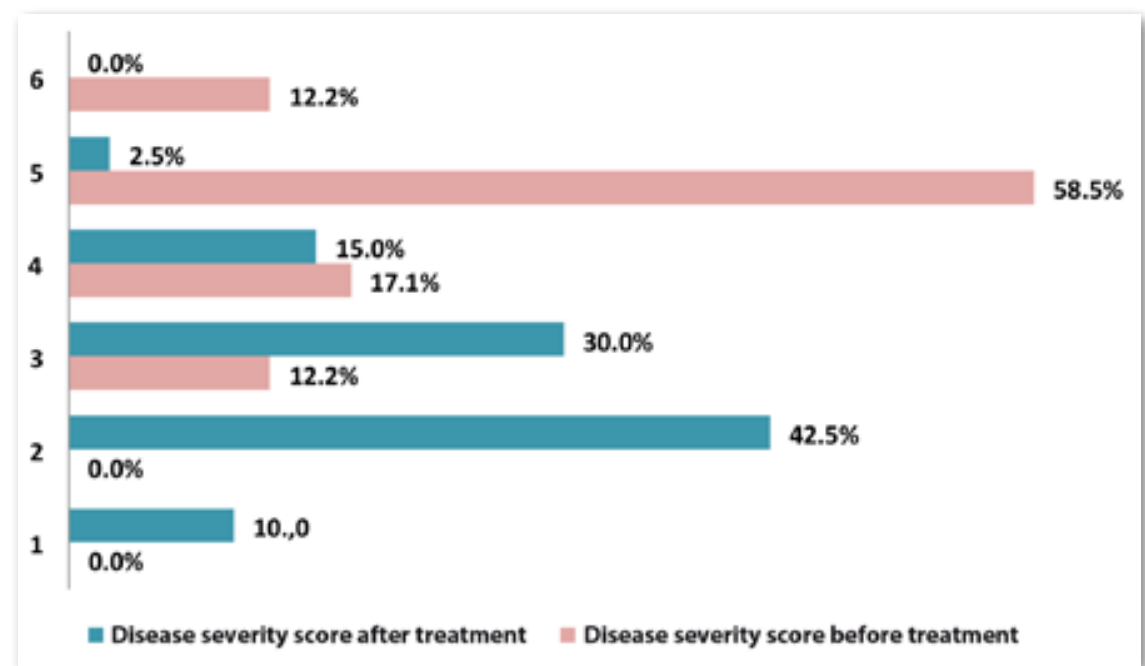

Figure 1: Distribution of disease severity scores before and after treatment according to the CGM-S 
(87.8\%) continued the treatment while $5(12.2 \%)$ discontinued the drug due to side effects (2 developed akathisia, 2 had irritability, and 1 reported drowsiness) within 1-3 weeks. There were no cases where the drug was discontinued due to unresponsiveness to treatment.

Improvement was defined as a decrease in intense impulsivity, oppositional defiant problems, excessive anger, and harming self and others in PDD, MR and ADHD; decrease in obsessions in OCD; decrease in tics in TD; improvement in mood, and decrease in anger and nervousness and general reduction of school problems in patients who go to school in BPD and depression. The mean CGM-S score was $4.7 \pm 0.85$ (markedly ill) at the beginning of treatment, and decreased to $2.3 \pm 0.97$ (borderline patients) in $42.5 \%$ of the cases at the end of the first month of treatment (Figure 1).

\section{DISCUSSION}

The objective of this article was to evaluate and share the treatment processes of cases that were followed at a public hospital outpatient department and were treated with aripiprazole as the antipsychotic of choice. The effectiveness of aripiprazole was evaluated in children and adolescents, who were diagnosed with autism, ADHD, DB, OCD, BPD, depression, TD coded in Axis 1, and MR and PD coded in axis 2 . Aripiprazole has been reported to be effective in ADHD, TD and OCD in addition to its use in schizophrenia, BPD and autism ${ }^{10,12-22}$. Aripiprazole was used off-label for some cases in our study as well. The drug was preferred in PDD and MR to treat the aggression, extreme reactivity and selfdestructive behavior, in ADHD cases to treat the intense impulsivity, aggressive behavior, and problems of confrontation and in BD and OCD patients as augmentation therapy. Aripiprazole is thought to be effective for the symptoms of the defined mental disorders. The CGN-S "markedly ill" mean value at the beginning decreased to "borderline ill" with the treatment. Bildik et al. reported a decrease in mental symptoms on the CGM-S after the use of aripiprazole in 7 cases diagnosed with BPD, schizophrenia, depression, OCD and MR in a case series from our country ${ }^{24}$.

Many studies and case presentations have reported the mean tolerated dose to be about 10 $\mathrm{mg} /$ day (28-31). Side effects were tolerated and the symptoms declined with a mean dose of $10 \mathrm{mg} /$ day in our study.

Fewer adverse effects or side effects are reported with aripiprazole than other typical and atypical antipsychotics in adult studies. Akathisia is the most common extrapyramidal side effect. Headache, insomnia, nausea, vomiting, somnolence, and constipation are frequently reported adverse side effects. Minimal weight gain has also been reported ${ }^{8}$. A meta-analysis reported the rate of discontinuation of aripiprazole treatment due to side effects in children with autism to be $10.4 \%(6.9 \% \text { for placebo })^{32}$. The rate of discontinuation of aripiprazole treatment was also determined in 302 adolescent schizophrenia patients in a double-blind, placebo-controlled study. No statistically significant difference was seen between the placebo and study groups ${ }^{12}$. At least one side effect was reported in $84.3 \%$ of 216 children with autism and 21 people discontinued the study due to a side effect in a double-blind, placebo-controlled study ${ }^{16}$. In 11 Tourette syndrome cases that used a mean aripiprazole dose of $4.5 \mathrm{mg} /$ day, appetite and weight gain was reported in 5, mild extrapyramidal side effects in 7 , headache and fatigue in 7 and akathisia and muscle pain in one case in another study where the side effect rate was high ${ }^{33}$. Side effects were seen in 9 (21.9\%) of our patients. Treatment was discontinued in $12.2 \%$ of the cases. Two of the 9 patients who developed side effects had used aripiprazole as their first antipsychotic. Akathisia occurred in 1 and sleep and drowsiness in the other of these 2 cases. The 7 other patients that developed side effects had a previous history of antipsychotic use and those antipsychotics had been discontinued due to side effects and unresponsiveness to treatment. In our study, patients who presented to the public hospital outpatient department for treatment were followed up. An attempt was made to increase treatment 
compliance with a dose adjustment and/or additional medication in patients who developed side effects. The incidence of side effects may therefore have been low. Some studies that reported a high rate of side effects were doubleblind, placebo-controlled follow-up studies and the presence of at least one mild side effect was recorded $^{12,16}$. The sample size of patients with Tourette disorder who reported side effects in all cases is small and the disorder group is a single diagnosis sample ${ }^{33}$. We evaluated side effects in a group consisting of patients with different diagnoses in our study. The low rate of side effects may also be due to the lack of measurements such as weight follow-up, the evaluation of side effects according to parent feedback and the limited number of cases. The lack of response to at least one antipsychotic drug and/or development of side effects are also important in 7 cases, who developed side effects with aripiprazole The data we have are not sufficient to associate the side effects with

\section{References:}

1. Kastrup A, Schlotter W, Plewnia C, Bartels M. Treatment of tics in tourette syndrome with aripiprazole. J Clin Psychopharmacol 2005;25(1):94-6. [CrossRef]

2. DeLeon A, Patel NC, Crismon ML. Aripiprazole: a comprehensive review of its pharmacology, clinical efficacy, and tolerability. Clin Ther 2004;26(5):649-66. [CrossRef]

3. Marder SR, McQuade RD, Stock E, Kaplita S, Marcus R, Safferman AZ, Saha A, Ali M, Iwamoto T. Aripiprazole in the treatment of schizophrenia: safetyand tolerability in short-term, placebo-controlled trials. Schizophr Res 2003;61(2-3):123-6. [CrossRef]

4. Fedorowicz VJ, Fombonne E. Metabolic side effects of atypical antipsychotics in children: a literature review. J Psychopharmacol 2005;19(5):533-50. [CrossRef]

5. Harrison-Woolrych M, Garcia-Quiroga J, Ashton J. Safety and usage of atypical antipsychotic medicines in children: a nationwide prospective cohort study. Drug Saf 2007;30(7):569-79. [CrossRef]

6. Alacqua M, Trifirò G, Arcoraci V, Germano E, Maqazu A, Calarese $\mathrm{T}$, et al. Use and tolerability of newer antipsychotics and antidepressants: a chart review in a paediatric setting. Pharm World Sci 2008;30(1):44-50. [CrossRef]

7. Pappagallo M, Silva R. The effect of atypical antipsychotic agents on prolactin levels in children and adolescents. J Child Adolesc Psychopharmacol 2004;14(3):359-71. [CrossRef] aripiprazole use, except in the first two cases.

We are sharing our experience in this study. Aripiprazole use led to an improvement in some mental disorders and symptoms in children and the side effects could be tolerated. However, the cases included in the study were selected among patients being followed up as outpatients in whom aripiprazole use was preferred and $46.3 \%$ had a history of at least one antipsychotic use. This is a limitation of the study. In addition, the use of other medications besides aripiprazole in some cases is another limitation when evaluating the effects and side effects. Other limitations were that the clinical improvement was determined based on the CGM-S as evaluated only by the clinician following the patient and there was no parent or teacher grading the severity of the symptom and there was also no control group. Double blind placebo controlled studies on aripiprazole use in children were also inadequate and one should therefore be careful about the usage, efficacy and side effect data of aripiprazole.

8. Rugino TA, Janvier YM. Aripiprazole in children and adolescents:clinical experience. J Child Neurol 2005;20(7):603-10.

9. Correl CU. Weight gain and metabolic effects of mood stabilizers and antipsychotics in pediatric bipolar disorder: a systematic review and pooled analysis of short-term trials. J Am Acad Child Adolesc Psychiatry 2007;46(6):687-700. [CrossRef]

10. Kirino E. Efficacy and safety of aripiprazole in child and adolescent patients. Eur Child Adolesc Psychiatry. 2012;21(7):361-8. [CrossRef]

11. Dogangun B, Kayacetin G, Kayaalp L. A reviewabout the use ofaripiprazole in children and adolescents. Turkish Journal of Child and Adolescent Mental Health 2008;15(3):163-75. (Turkish)

12. Findling RL, Robb A, Nyilas M, Forbes NA, Jin N, Ivanova S, et al. A multiple-center, randomized, double-blind, placebocontrolled study of oral aripiprazole for treatment of adolescents with schizophrenia. Am J Psychiatry 2008;165(11):1432-41. [CrossRef]

13. Durkin JP. Aripiprazole in the treatment of bipolar disorder in children and adolescents. J Child Adolesc Psychopharmacol 2004;14(4):505-6. [CrossRef] 
14. Findling RL, Youngstrom EA, McNamara NK, Stansbrey RJ, Wynbrandt JL, Adegbite C, et al. Double-blind, randomized, placebo-controlled long-term maintenance study of aripiprazole in children with bipolar disorder. J Clin Psychiatry 2012;73(1):57-63. [CrossRef]

15. Biederman J, McDonnell MA, Wozniak J, Spencer T, Aleardi M, Falzone R, et al. Aripiprazole in the treatment of pediatric bipolar disorder: a systematic chart review. CNS Spectr 2005;10(2):141-8.

16. Marcus RN, Owen R, Kamen L, Manos G, McQuade RD, Carson WH, et al. A Placebo-Controlled, Fixed-Dose Study of Aripiprazole in Children and Adolescents With Irritability Associated With Autistic Disorder. J Am Acad Child Adolesc Psychiatry 2009;48(11):1110-9. [CrossRef]

17. Basgul S, Uneri Ozden. Poster Communication. 14 $4^{\text {th }}$ International Congress of ESCAP - European Society for Child and Adolescent Psychiatry 11-15 June 2011, Finland.

18. Murphy TK, Bengtson MA, Soto O, Edge PJ, Sajid MW, Shapira N, et al. Case series on the use of aripiprazole for Tourette syndrome. Int J Neuropsychopharmacol 2005;8(3):489-90. [CrossRef]

19. Duane DD. Aripiprazole in childhood and adolescence for Tourette syndrome. J Child Neurol 2006;21(4):358. [CrossRef]

20. Findling RL. Atypical antipsychotic treatment of disruptive behavior disorders in children and adolescents. J Clin Psychiatry 2008;69(Suppl 4):S9-S14.

21. Bloch MH, Landeros-Weisenberger A, Kelmendi B, Coric V, Bracken MB, Leckman JF. A systematic review: antipsychotic augmentation with treatment refractory obsessivecompulsive disorder. Mol Psychiatry 2006;11(7):622-32. [CrossRef]

22. Findling RL, Short EJ, Leskovec T, Townsend LD, Demeter CA, McNamara NK, et al. Aripiprazole in children with attention-deficit/hyperactivity disorder. J Child Adolesc Psychopharmacol 2008;18(4):347-54. [CrossRef]

23. Ercan ES, Uysal T, Ercan E , Ardic UA. Aripiprazole in children and adolescents with conduct disorder: a singlecenter, open-label study. Pharmacopsychiatry 2012;45(1):139. [CrossRef]
24. Bildik T, Ozbaran NB, Kucukkose M, Ardic UA. Aripiprazole use in children and adolescents: a case series. Klinik Psikofarmakoloji Bulteni-Bulletin of Clinical Psychopharmacology 2010;20(1):84-93. (Turkish)

25. American Psychiatric Association. Diagnostic and statistical manual of mental health disorders $\left(4^{\text {th }}\right)$. Washington DC: Am Psychiatric Publishing, 1994.

26. Guy W. Assessment Manual for Psychopharmacology. Rockville, MD: US Department of Health and Human Services Publication (ADM) 1976;218-22.

27. Leckman JF, Riddle MA, Hardin MT, Ort SI, Swartz KL, Stevenson J, et al. The Yale Global Tic Severity Scale: initial testing of a clinician-rated scale of tic severity. J Am Acad Child Adolesc Psychiatry 1989;28(4):566-73. [CrossRef]

28. Stigler KA, Posey DJ, McDougle CJ. Aripiprazole for maladaptive behavior in pervasive developmental disorders. J Child Adolesc Psychopharmacol 2004;14:(3)455-63. [CrossRef]

29. Biederman J, Mick E, Spencer T, Doyle R, Joshi G, Hammerness P, Kotarski M, et al. An openlabel trial of aripiprazole monotherapy in children and adolescents with bipolar disorder. CNS Spectr 2007;12(9):683-89.

30. Tramontina S, Zeni CP, Pheula GF, de Souza CK, Rohde LA. Aripiprazole in juvenile bipolar disorder comorbid with attention-deficit/hyperactivity disorder: an open clinical trial. CNS Spectr 2007;12(10):758-62.

31. Barzman DH, Del Bello MP, Kowatch RA, Gernert B, Flek DE, Pathak S, et al. The effectiveness and tolerability of aripiprazole for pediatric bipolar disorders: a retrospective chart review. J Child Adolesc Psychopharmacol 2004;14(4):593-600. [CrossRef]

32. Adelaide SR, Candace A, Elizabeth EB, George M, Carlos RF, Suja M, et al. Safety and Tolerability of Aripiprazole in the Treatment of Irritability Associated With Autistic Disorder in Pediatric Subjects (6-17 Years Old): Results From a Pooled Analysis of 2 Studies. Prim Care Companion CNS Disord 2011;13(1):1-9.

33. Lyon GJ , Samar S , Jummani R , Hirsch S, Spirgel A, Goldman $\mathrm{R}$, et al. Tourette bozukluğu olan çocuk ve ergenlerde aripiprazol: Bir açık etiketli güvenlik ve tolerabilite çalışma. J Child Adolecs Psvchopharmacol Ara 2009;19(6):623-33. [CrossRef] 